\title{
School Partnerships and Principals' Administrative Effectiveness in Secondary Schools in Ibesikpo Asutan Local Government Area of Akwa Ibom State, Nigeria
}

\author{
Aloysius Okon Umosen, Ph.D ${ }^{1} \&$ Patricia Ogon ${ }^{2}$ \\ Institute of Education and Professional Development, University of Uyo, Uyo, Nigeria \\ E-mail: ${ }^{1}$ umosenaloysius@gmail.com; ${ }^{2}$ suyang74@yahoo.com
}

\begin{abstract}
The study investigated the influence of school partnerships on principals' administrative effectiveness in secondary schools in the Ibesikpo-Asutan Local Government Area of Akwa Ibom State, Nigeria. The study adopted an expost facto research design. The target population comprised all the principals, vice-principals, and teachers, totaling 328. The sample of the study consisted of 176 respondents, comprising seven principals, 14 viceprincipals and 155 teachers representing, $50 \%$ of the teachers in each of the schools. Researchers developed an instrument titled: School Partnerships and Principals Administrative Effectiveness Questionnaire (SPPAEQ) with a reliability coefficient of 0.83 that was used for data collection. The data collected were analyzed using simple linear regression. The null hypotheses were tested at 0.05 level of significance. The results revealed that partnerships with religious organizations and host communities have a significant influence on principals' administrative effectiveness. It was recommended, among other things, that the principals of secondary schools should nurture good relations with the host communities. These include but not limited to contributions to social and cultural activities, educational counseling services, and other fruitful exchanges between the school and the host community. For instance, industrial engagements in training and education should be pursued by principals in the host communities.
\end{abstract}

Keywords: School partnership, School Administration, Principals administrative effectiveness

DOI: $10.7176 / \mathrm{JEP} / 11-30-17$

Publication date:October $31^{\text {st }} 2020$

\section{Introduction}

The term administration, is the process by which material and financial resources are maximally harnessed to achieve organizational set goals through collective and cooperative human effort in a conducive environment. Armstrong (2006) posits that administration includes the function like management of the affairs with the use of well thought out principles and practices like budgeting, staffing, evaluation along with the processes such as leadership, organization, communication and coordination.

On the other hand, administrative effectiveness refers to the ability of the school administrator to carry out administrative tasks related to instructional management, internal relation, organizational management, students' performance and school community relations towards achieving the school objectives. Also, it is the management skills, possessed by an individual to run an organization in an easy and efficient manner.

Principal administrative effectiveness is the efficient application of skills to run an institution in a manner that is fulfilling to all the stakeholders of education including, the teachers, students, parents, and society. Brewer (2001) asserts that a principal is claimed to exhibit administrative effectiveness when he is capable of carrying out the assigned roles, such as focusing on modern instructional techniques, building a community of learners, sharing decision making, sustaining time management techniques and supporting professional development for all staff members. Also, the principal should ensure efficient and equitable management of resources, creation of a climate of integrity, inquiry, and school partnership with education stakeholders.

Tanveer and Khan (2014) opine that an administration is considered smooth and enjoyable if the administrator is endowed with desired personality traits and management skills, otherwise the administration will be full of tension. Also, an administration is encumbered by lack of adequate funding, infrastructure, instructional resources, and the likes where no collaborations exist. The absence of collaboration implies that the principal cannot work in isolation of other support groups, to successfully achieve the set objectives of the secondary schools in Akwa Ibom State. Worst still are the various unmet demands of the teachers, students, parents and even the society. For this reason, the school partnership becomes very apt and a panacea for meeting the excessive needs of the education 
stakeholders.

School partnership is an innovation whereby schools work together with identified partners to strengthen, support and even transform individual partners (schools/institutions) resulting in improved programme quality, more efficient use of resources, better alignment of goals and curricula (Harvard Family Research Project (HFRP), 2010). School partnership further enhances students' skills by building an efficient workforce for the future, promotes organizational image and visibility by providing a valued community service, internship and job training; provides financial assistance, goods and services to the school (Howard County Public School System (HCPSS), 2009).

The benefits are that the more the principals collaborate with various independent groups, the more likely they can address the global challenges in the school system. These partnerships bring together different groups, such as religious organizations, Parent Teachers Association (PTA), the host community, etc. The aim of the partnership is to expand the opportunities for knowledge creation, dissemination, and acquisition among the students through financial supports for the employment of qualified staff, book supplies to the libraries, construction of school buildings, etc. Meanwhile, many principals tend to be oblivious of the opportunities inherent in school partnerships in terms of the developmental prospects of the school system. It is against this background that the study is poised to investigate the influence of school partnerships on principals' administrative effectiveness in secondary schools in Ibesikpo-Asutan Local Government Area of Akwa Ibom State, Nigeria.

There are several complexities that tend to limit the degree to which secondary school principals in IbesikpoAsutan Local Government Area can be effective, especially considering the large and increasing students' enrolments amidst grossly inadequate and obsolete infrastructural facilities. On the other hand, the principals tend to contribute to the problem especially when they lack proper coordination. Sometimes, the principals are accused of negligence, laziness, permissiveness, lack of dedication, and zeal to work. These issues suggest that something is fundamentally wrong with the performance or effectiveness of the public secondary schools' principals. The consequence of this problem is the poor academic performance of students. Therefore, the study aims at investigating the influence of school partnerships on principals' administrative effectiveness in the secondary schools in the Ibesikpo-Asutan Local Government Area of Akwa Ibom State, Nigeria.

\subsection{Research Questions}

The following research questions guided the study:

1. What is the influence of school partnerships with the religious organization on principals' administrative effectiveness in secondary schools?

2. What is the influence of school partnerships with the host community on principals' administrative effectiveness in secondary schools?

\section{$1.2 \quad$ Null Hypotheses}

The following hypotheses were testes in the study:

1. There is no significant influence of school partnerships with the religious organizations on principals' administrative effectiveness in secondary schools.

2. There is no significant influence of school partnerships with the host community on principals' administrative effectiveness in secondary schools.

\section{Theoretical Framework}

The Situated Learning Theory by Lave, J. and Wenger, E. (1991) provides the theoretical framework for this study. According to Lave and Wenger (1991), the theory focuses on the relationship between learning and certain forms of social co-participation. The theorists argued that learning is a social process whereby knowledge is constructed and meaningfully propagated for the benefit of the individual learner and society. The theorists further articulated that learning is situated in a specific context and embedded with a particular social and physical environment to ensure its sustainability. This implies that schools cannot survive in isolation of viable co-contributors. Thus, there must be co-participations with the community, individuals, groups, and institutions.

The conditions laid by the situated learning theory give the principal a situated context to solve the problem of providing the immediate needs of the school by partnering. Lave and Wenger (1991) refer to these groups as communities of practice that can be formal or informal. Communities of practice contain three components, namely; joint enterprise, mutual engagement, and a shared repertoire. The relevance of the theory to this study is that partnerships can be developed to include diverse groups of old students of the institutions 
(Alumni), philanthropists, Parents Teachers Association (PTA), host communities, etc, so that they can render some educational services to the school's system. These services will, in turn, lessen the stress borne by the principals while promoting administrative effectiveness elicited from the useful inputs in the environment injected into the day-to-day running of the school.

\section{Review of Literature}

School partnership with religious organizations and principals' administrative effectiveness is proposed to have a relationship worthy of research attention. The history of modern education in Nigeria could be traced to the religious organizations, especially the Christian Mission (Fafunwa, 2004). Religious organizations are groups of religious bodies or churches that function through organizations with specific goals (Oladipo, 2013). In Nigeria, the religious organizations include, the Islamic organization and Christian organization. For this study, the scope would be limited to Christian religious organizations since the study area is predominantly Christians. These groups have on a regular basis provided to the various secondary schools, some monetary and material donations, as well as offer for use some church spaces and facilities to promote the teaching and learning activities in secondary schools in Ibesikpo-Asutan Local Government Area.

Ekpendu, Audu, and Ekpendu (2016) conducted a study on evaluation of the role of religious organizations in the development of schools in Nigeria. Qualitative and descriptive method of inquiry was used in the study. It was discovered that the religious groups had played starring roles in educational growth in Nigeria through the provision of school infrastructure, donation of books and other educational resources. Also, the religious organization ensured the inculcation of morals through teaching, seminars, and symposia in schools.

Ngussa and Makewa (2018) investigated the role of Christian Religious Education in secondary school students' discipline in Lake-zone, Tanzania. A survey research design was used to gather data from teachers and students in 19 sampled schools, using questionnaires, interview schedules and focus group discussion. The data obtained were analyzed using descriptive statistics. The study revealed that Christian Religious Education prepared learners to be morally upright. Also, there was a significant difference in teachers' ratings on the frequency of disciplinary cases between schools that teach CRE and those which do not teach the subject.

School partnership with the host community and principals' administrative effectiveness is also believed to have a relationship worthy of research attention. Community collaboration with schools complements and reinforces values, culture and learning opportunities that most schools cannot provide for their students. These partnerships make schools more efficient in working towards the attainment of their set objectives. Kladifko (2013) opines that the effective partnership of the host communities with the school encourages the principal to seek assistance in monitoring the school in terms of possible vandalism during holidays.

Ataine and Nkedishu (2017) conducted a study on community relations in the development of primary education in Delta State, Nigeria. The study adopted a descriptive survey design. The population was 16,961 head teachers, assistant head teachers and teachers in primary schools and community elders in Delta State. From the population, 1696 respondents were selected using a proportionate stratified random sampling technique. Researchers' developed questionnaire titled: School Community Relation and Development of Primary Education Questionnaire (SCRDPEQ) was used for data collection. Data collected were analyzed using descriptive statistics of the mean score and standard deviation. The study revealed, among other things, that the community provides land for building primary schools, helps in funding the primary schools, helps in providing more classrooms in the primary schools. On the other hand, the community makes use of the school open space during elections, its classrooms for community meetings when the school is not in session; schools playground are used for local games as well as organize cultural displays during festive seasons.

Ogundele, Oparinde and Oyewale (2012) investigated the relationship between community school relations and principals' administrative effectiveness in secondary schools in Kwara State. A correlational survey research design was employed for the study. Two thousand respondents comprising the principals, vice-principals, PTA executive, and representatives of religious bodies were selected using a stratified random sampling technique. The study employed Community Schools Relations and Principal Administrative Effectiveness Questionnaire (CSRPAEQ) for data collection while the Pearson Product Moment Correlation statistic was used for data analysis at 0.05 significance level. The findings revealed that high significant relationship exists between community school relations, and principal administrative effectiveness, school plant provision and maintenance, as well as instructional material development for the secondary schools. 


\section{5. $\quad$ Research Methods}

The ex-post facto research design was adopted for this study. The design was considered appropriate because the variables were assumed to have occurred without being subjected to any form of manipulation. The target population was 328 school personnel comprising seven principals, 14 vice-principals, and 307 teachers. A random sampling of 50 percent of the teachers were selected from each school numbering 155 teachers, while the census method was used to select seven principals and 14 vice-principals totaling 176 respondents.

Researchers' self-developed instrument titled: School Partnerships and Principals' Administrative Effectiveness Questionnaire (SPPAEQ) was employed for data collection. SPPAEQ instrument was based on a four-point rating scale with Strongly Agree (SA) being four (4) points and Strongly Disagree (SD) one (1) point for the positively worded items. At the same time, reverse scoring was used for negative items. The reliability of the instrument was obtained using Cronbach's Alpha reliability method, which yielded a 0.83 reliability coefficient The questionnaires were administered to the 176 respondents in their respective schools and $100 \%$ return rate obtained. Data were analyzed using simple linear regression to test the null hypotheses at 0.05 level of significance.

\section{Results}

Research Question 1: What is the influence of school partnerships with the religious organizations on principals' administrative effectiveness in secondary schools?

Table 1: Summary of Linear Regression test for influence of school partnerships with religious organizations on principals' administrative effectiveness

\begin{tabular}{ccccc}
\hline & \multicolumn{2}{c}{ Unstandardized coefficients } & & Standardized coefficients \\
\cline { 2 - 5 } & Model & B & Std. Error & Beta \\
\hline \multirow{2}{*}{1} & (Constant) & 2.219 & .228 & \\
\hline & Rel. Partnership & 0.231 & .078 & .22 \\
\hline
\end{tabular}

Table 1 shows the summary of the regression test for the influence of school partnerships with the religious organizations on principals' administrative effectiveness. The table shows the regression coefficients. For every unit rise in religious organization partnerships, principals' administrative effectiveness increases by 0.231 . Furthermore, the correlation index (r) is 0.22 , indicating a weak positive relationship between religious organization partnerships and principals' administrative effectiveness. The coefficient of determination $\mathrm{R}^{2}=0.049$, showing that $4.9 \%$ changes in administrative effectiveness are as a result of religious organization partnerships.

Research Question 2: What is the influence of school partnerships with the host community on principals' administrative effectiveness in secondary schools?

Table 2: Summary of Linear Regression Test for the influence of school partnerships with the host community on principals' administrative effectiveness

\begin{tabular}{ccccc}
\hline & \multicolumn{2}{c}{ Unstandardized coefficients } & & Standardized coefficients \\
\cline { 2 - 5 } & Model & B & Std. Error & Beta \\
\hline \multirow{2}{*}{1} & (Constant) & 2.016 & .196 & \\
& Comm. Partnership & .308 & .067 & .33 \\
\hline
\end{tabular}

$$
\mathrm{r}=0.33 ; \mathrm{R}^{2}=0.109
$$

Table 2 shows the summary of the regression test for the influence of school partnerships with the host community on principals' administrative effectiveness. The table shows the regression coefficients. For every unit rise in community partnerships, principals' administrative effectiveness increases by 0.308 . The correlation index (r) is 0.33 , indicating a positive relationship between the host community partnerships and principals' administrative effectiveness. The coefficient of determination $\left(\mathrm{R}^{2}\right)$ is 0.109 , showing that $10.9 \%$ changes in administrative effectiveness are as a result of community partnerships.

\section{Null hypotheses}

$\mathrm{H}_{\mathrm{ol}}$ : There is no significant influence of school partnerships with the religious organizations on principals' administrative effectiveness in secondary schools. 
Table 3: Regression for the influence of school partnerships with the religious organizations on principals'

administrative effectiveness

\begin{tabular}{cccccccc}
\hline & Model & $\begin{array}{c}\text { Sum of } \\
\text { Squares }\end{array}$ & df & $\begin{array}{c}\text { Mean } \\
\text { Square }\end{array}$ & $\mathbf{F}_{\text {cal }}$ & F $_{\text {crit }}$ & Decision \\
\hline 1 & Regression & 7.091 & 1 & 7.091 & 8.882 & 3.94 & $*$ \\
& Residual & 138.904 & 174 & .798 & & & \\
& Total & 145.994 & 175 & & & & \\
\hline
\end{tabular}

* Significant at 1 and 174 degrees of freedom and 0.05 alpha level

Table 3 shows a summary of the f-test for significance. The result indicates that the calculated $f$ value is 8.882 at 1 and 174 degrees of freedom and 0.05 alpha level, the critical $f$ value $\left(F_{\text {crit }}\right)$ is 3.94 . Since $F_{\text {cal }}$ is greater than $F_{\text {crit, }}$ the results are statistically significant, and the null hypothesis is rejected. Thus, there is a significant influence of school partnerships with the religious organizations on principals' administrative effectiveness in secondary schools.

$\mathrm{H}_{\text {o2: }} \quad$ There is no significant influence of school partnerships with the host community on principals' administrative effectiveness in secondary schools.

Table 4: Regression test for significant of school partnerships with the host community on principals'

\begin{tabular}{cccccccc}
\hline \multirow{2}{*}{ Model } & Sum of & df & $\begin{array}{c}\text { Mean } \\
\text { Square }\end{array}$ & $\mathbf{F}_{\text {cal }}$ & $\mathbf{F}_{\text {crit }}$ & Decision \\
\hline 1 & Rquares & & 1 & 15.927 & 21.306 & 3.94 & $*$ \\
& Regression & 15.927 & 1 & & & \\
Residual & 130.068 & 174 & .748 & & & \\
Total & 145.994 & 175 & & &
\end{tabular}

Table 4 shows a summary of the f-test for significance. The result indicates that the calculated $F$ value is 21.306 at 1 and 174 degrees of freedom and 0.05 alpha level. The critical $f$ value $\left(F_{\text {crit }}\right)$ is 3.94 . Since $F_{\text {cal }}$ is greater than the $F_{\text {crit, }}$, the result is statistically significant, and the null hypothesis is rejected. Thus, there is a significant influence of school partnerships with the host communities on principals' administrative effectiveness in secondary schools.

\section{Discussion of the Findings}

School partnership with religious organizations and principals' administrative effectiveness was proposed to have a relationship. The corresponding hypothesis test shows that there is a significant influence of school partnerships with the religious organizations on principals' administrative effectiveness in secondary schools. The finding agrees with a similar study by Ekpendu, Audu, and Ekpendu (2016), which found that religious groups have played starring roles in educational growth in Nigeria through the provision to schools, donation of educational resources to schools, and inculcating morals through teaching, seminar and symposia done in schools.

School partnership with host community and principals' administrative effectiveness in secondary schools was also proposed to have a relationship. The study shows that there is a significant influence of school partnerships with the host communities on principals' administrative effectiveness in secondary schools. This finding aligns with an earlier study by Atanine and Nkedishu (2017), which found a positive influence of school partnerships with the host communities and enhanced effectiveness. The finding also corroborated by Ogundele, Oparinde, and Oyewale (2012), which indicated a significant relationship between the school partnerships with the host communities in the area of provision and maintenance of school plants in the secondary schools.

\section{Conclusion and Recommendations}

Based on the findings of the study, it is concluded that school partnerships with the religious organizations and host communities have a significant influence on principals' administrative effectiveness. Thus, school partnerships have a significant influence on principals' administrative effectiveness in secondary schools in Ibesikpo-Asutan Local Government Area of Akwa Ibom State, Nigeria. Based on the findings and conclusion of this study, the following recommendations are made:

1. Principals' should continue to collaborate with the religious organizations in the area of moral education to reduce the tide of moral decadence in the society, as well as the provision of educational resources to enhance academic excellence in secondary schools in Ibesikpo Asutan Local Government Area of Akwa Ibom State, Nigeria. 
2. Principals of secondary schools should develop and sustain good relations with their host communities as such symbiotic relationships will enhance the safety of school property against vandalism, among other things.

\section{References}

Armstrong, M. (2006). Human resource management practice (10th ed.) London: Kogan page Limited.

Ataine, A. J. \& Nkedishu, V. C. (2017). Relevance of school community relations in the development of primary education in Delta State. Journal of Research in Education and Society, 8(2): 18-27.

Brewer, H. (2001). Ten steps of success. Journal of Staff Development, 22(1): 30-31.

Ekpendu, G. I., Audu, S. D. \& Ekpendu I. C. (2016). An evaluation of the role of religion in the development of Nigeria. Journal of Developing Country Studies, 6(100): 22-29.

Fafunwa, A. B. (2014). History of education in Nigeria. Ibadan: Ups Educational Publishers Limited.

Havard Family Research Project (2010). Partnership for learning, promising practice, integrating school and outof-school time programme. Retrieved from https://www. hfrp.org/publication-resources/browse-ourpublication/partner on 25/6/2020.

Howard County Public School System (2019). Benefits of school partnership. Retrieved from https://www.hcpss.org on 27/6/2020.

Kladifko, R. E. (2013). Practical school community partnership leading in successful educational learners. The Journal of California Association of Professors of Educational Administration, 24, 54-61.

Lave, J. \& Wenger, E. (1991). Situated learning: legitimate peripheral participation. Cambridge: University of Cambridge Press.

Ngussa, B. M. and Makewta, L. N. (2018). Role of Christian religious education on Secondary School Student discipline in lake zone, Tanzania. Journal of Research innovation and Implications in Education. Online: 2520 7504; (JRIIE).

Ogundele, M. O., Oparinde, F. O. \& Oyewale, M. K. (2012). Community school relations and principals' administrative effectiveness of secondary schools in Kwara State. Journal of Educational Social Research, 2(3): 271-275.

Tanveer, A. and Khan, B. (2014). The challenges of university administration. Journal of Education Policy, Planning and Administration (JEPPA), 9(5): 95-110. 